\title{
Looking into the Recent Past \\ Extending and Exploring the Field of Archaeology
}

\author{
Mats Burström
}

\begin{abstract}
The archaeology of the recent past is a growing field of research. Is this merely a chronological extension of the field of archacology, or is it something more? What motivates an archaeological interest in a period of time for which there are so many other sources of information? Here it is argued that the archaeology of the recent past is important not only to bring to light other stories than those generally told, but also to bring to the fore theoretical issues of general relevance for archaeology. The latter concern what material remains can be more than just potential sources of information about the past.
\end{abstract}

Mats Burström, Department of Culture and Communication, Södertörn University College, SE-14189 Huddinge, Sweden.

Key words: recent past, emotional dimension, existential reflection, memory, anecdotes, fragmentary form.

More and more archaeologists are looking into the recent past. These studies are no longer mainly intended as pedagogical tools for teaching basic archaeological methods, or as an experimental field for formulating behavioural laws for archaeology proper (cf. Gould \& Schiffer 1981; Welinder 1992:8-13, 1993b:109). Instead, the archaeology of the recent past is now considered to exist in its own right and have a value in itself. It can produce other stories about the recent past than those that dominate history, and it raises important questions as to how material objects affect people in different ways (cf. Buchli \& Lucas 2001; Burström 2007a). The latter are relevant to all archaeology and lead further to epistemological considerations; a central issue is whether there is room in archaeology as a scholarly discipline to include emotional dimensions and existential reflections (cf. Renfrew 2003).

\section{NARROWING DOWN THE FIELD}

First of all, let us consider when the recent past starts. This question is, no doubt, rather like asking how long a string is, but nevertheless it is an issue that must be confronted. All history is written looking out from the present; the present influences what questions we choose to ask, as well as which answers we find 
reasonable. This means that all archaeological interpretations are related to the time they were made and to some extent reflect that time. This is a fundamental reason that the interpretation of the past is a never-ending story. Each generation writes history in its own way.

Carried to its extreme, this constructivist perspective could be used to argue that all archaeology is actually archaeology of the recent or the contemporary past. This would imply that the present influences our archaeological interpretations so much that they primarily reflect ourselves and tell us very little, if anything, about the distant past. I think that would be to carry the perspective too far and that it would be to underestimate the importance of the material record. Archaeological interpretations are more than simple projections of the present. Such an all-inclusive view on the archaeology of the recent past would also deprive the concept of its usefulness in any more precise meaning.

Any attempt to define the field of research for the archaeology of the recent past in chronological terms meets with difficulties. And one might indeed ask how important such a definition is. For such a relatively new field of research, I believe it is important to have an open attitude concerning its conceptual limits. A strict definition carries the risk of restraining thought just as much as promoting clarity. But for the sake of discussion I nevertheless think it is necessary to make some sort of operational demarcation here.

One aspect of the archaeology of the recent past that I find particularly interesting is the relation between materiality and memory. Material remains seem to have a remarkable power to evoke people's memories and their stories about the past. People's memories are also something you constantly have to relate to when studying the recent past. My starting-point for narrowing down the field of the archaeology of the recent past in chronological terms is therefore how far back in time people's memories stretch.

Memories are a complicated source of information. Sometimes they recall events that actually once took place, and sometimes they are later constructions - conscious or not - that help a person to understand the past and its remains, or perhaps even make them bearable. What is what, is often not clear, and not least to the person who has the memory. People also take over each other's memories, and it can be difficult for them to determine what they themselves have experienced and what others have told them. Most of us are, for example, not sure whether we actually remember certain episodes from our childhood, or if what we remember are stories we have been told by others. And sometimes when we are sure, we are actually wrong.

Memories may thus be deceptive. But regardless whether they are historically correct, memories are important to people and give them a special relation to the recent past. Stories told by someone who has personally experienced what he or she is describing are generally considered to have special weight. As first-hand sources and eyewitness accounts they are supposed to have great credibility. If we include memories that people alive today have heard others tell about 
experiences of their own, the memories stretch two generations back in time. What does this mean in years? A person who today is 90 years old can have memories that reach back to at least the age of ten. In that case we are 80 years back in time. If he or she then met someone who in the same way could remember 80 years back in time, we are in all 160 years back in time. Let us for the sake of simplicity say that, with the memories of two generations, we can reach back to c. 1850. In Sweden this coincides with what is considered as the time for the breakthrough of the industrial society (Isacson 2003:37-39). It is also the nearer limit in time for the period usually studied within historical archaeology in Sweden (Wienberg 2005). It seems reasonable that the archaeology of the recent past should begin where historical archaeology ends in practice. This means that industrial archaeology in Sweden here is considered as a part of the archaeology of the recent past.

Here I will use the concept "archaeology of the recent past" to denote archaeological studies of the period from 1850 to the present day. In other contexts the concept is - as with many other chronological periods or concepts, e.g., the Mesolithic or the Middle Ages - used with other meanings. It has, for example, been suggested that the $20^{\text {th }}$ century should be called "the recent past", and the past of which we have personal experience "the contemporary past" (Schofield 2005:29).

\section{THE ABUNDANCE OF SOURCES}

The period from 1850 until today has left us an abundance of sources of information; both in number and in variation they exceed the sources available from the rest of human history. These numerous and diverse sources are studied by a number of academic disciplines specialising in different aspects of the recent past. The obvious question is what archaeology could possibly add to this.

Let us first of all state that having a large number of sources of information does not guarantee the writing of a multivocal history that provides room for many voices and different perspectives. To quote the American author Samuel McChord Crothers (1903): "The trouble with facts is that there are so many of them". The abundance of sources makes the recent past difficult to grasp. The result is that some histories dominate and are repeated over and over again, while other stories cannot make themselves heard (cf. Buchli \& Lucas 2001:14). By approaching the $19^{\text {th }}$ - and $20^{\text {th }}$-century past from a different kind of source than the usual, it is possible for archaeology to find and give voice to other stories than those dominating history.

The stories dominating the history of the recent past are usually concerned with a very high and general level. The abundance of sources is handled through a condensation of history to what in retrospect appears to be the most important processes and course of events. These stories usually deal with technical development, economical structures, and political conditions. This is a completely reasonable way to outline the recent past, and it brings out important causal connections. 
But this way of describing what once was also differs considerably from how most people at the time experienced it. By approaching the past from a more down-to-earth perspective, the archaeology of the recent past can reveal other aspects of life as well as how the big history expressed itself and influenced people in their everyday life. This is the same perspective that is usually applied within oral history (cf. Hansson \& Thor 2006).

Material remains from the recent past can be used both to complement and to contrast other kinds of sources. The complement function applies to contexts that have not been documented in other ways. These are often related to economically poor people and those who for other reasons have lived outside ordinary society, or to certain types of activities such as craftsmanship techniques. The complement function is also one reason for excavating sites where, for example, aeroplanes crashed during the Second World War (cf. Taylor 1999; Legendre 2001). An excavation can, at best, reveal what caused the specific crash and what happened to the crew; to obtain knowledge of this is often of great value indeed for surviving relatives. Uncovering the fate of individual persons with names and families is also an effective reminder of the horrors of war, for all of us. It personalises a history that otherwise may be difficult to comprehend. Since many types of aeroplanes are not preserved in any other way, the remains at crash sites are also an important source of information for aircraft history (cf. Holyoak \& Schofield 2002).

Perhaps the best example of the contrast function of material remains is also the most well-known example of the archaeology of the recent past: namely, The Garbage Project which was led by William Rathje and which started in the US in 1973 and then continued for almost three decades. The project studied people's ways of life by comparing what they themselves reported in interviews and questionnaires about their consumption with what was actually found in their garbage. The differences proved to be considerable (e.g., Rathje 2001; Rathje \& Murphy 2001).

One of these differences concerned the consumption of alcohol. The Garbage Project showed that the consumption as witnessed by people's refuse was $40-60$ percent higher than what they reported in interviews and questionnaires (Rathje 2001:64). There may be several reasons for this striking difference. Some may, when asked, have wanted to give what they thought was a more positive picture of themselves, although they participated anonymously in the study. At the outset of the project Rathje thought that the participants intentionally might be misreporting, but later he came to the conclusion that people are unaware of their actual consumption and think they live another life than they actually do (Rathje 2001:67). Both alternatives generate thought-provoking questions about parallel realities. Do we say we live other lives than we do? Or do we experience other lives than those we actually live? Can material objects help us discover this? Do we want to discover it? 


\section{EVOKING INTEREST}

Besides being important as a complement and a contrast to other kinds of sources of information, material remains are also important for bringing the recent past to the fore and evoking an interest in it. Material objects have the power to attract attention and arouse curiosity; this is especially true of objects found in excavations. This context seems to be able to give almost any object, regardless of how ordinary it might seem, a suggestive power that stimulates people's imagination and gives rise to questions about the past.

In the last few years there have been a number of archaeological excavations in Sweden specifically dealing with sites from the recent past. These have dealt with crofter's cottages (Sw. torp; e.g., Welinder 1992, 1993a, 1993b; Lind \& Svensson 2001; Ulin 2004; Bodin et al. 2005), internment camps from the Second World War (Fåhraeus et al. 2005; Lihammer 2006; Burström 2007a:37-38), a settlement for Romanies (Hammar \& Lindholm 2005; Lindholm 2006), an openair dance floor (Persson 2006), the crash site for a German V2-rocket (Burström, Gustafsson \& Karlsson 2006), and a jetty (Sw. klappbrygga; www.tidaholm.se/ kultur/klappeb_arkeologi.htm). None of these excavations has revealed any spectacular finds that can be alleged to have altered our knowledge of history in a profound way. But they have all attracted a great deal of local attention, and they have engaged a lot of people who in many cases also have taken an active part in the archaeological work and the interpretation. There has also been a lot of media coverage with reports in local newspapers, radio and television. The excavations and the everyday objects found in the ground have generated conversations about the past that otherwise would never have taken place, and these have in turn led to a remembering process and to new questions being asked. In this way the excavations have brought the recent past to the fore and made it an issue to many people.

Also remains that are well visible above the ground have a power to evoke an interest in the recent past. One example is what the French cultural-theoretician Paul Virilio calls his "bunker archaeology". It started by coincidence in the summer of 1958; temporarily bored with the seaside games at a beach in Brittany, Virilio started to examine the bunker he happened to be leaning on a little more carefully. It had once formed part of Hitler's Atlantic Wall, but the narrow space Virilio encountered inside the bunker reminded him of an ancient tomb and evoked his further interest. Long walks along the Brittany coast revealed that it was possible to walk day after day without ever losing sight of bunkers. They reminded him of a subterranean civilisation that had sprung up from the ground, and he was fascinated (Virilio 1994:10-12).

This fascination for the material remains of the Atlantic Wall led Virilio further along the European shores (cf. Fig. 1) and into a research that soon came to include many different sources of information. What is important to notice, however, is that it all started with the close contact with a physical remnant - the bunker he happened to be leaning on. This experience illustrates the great 


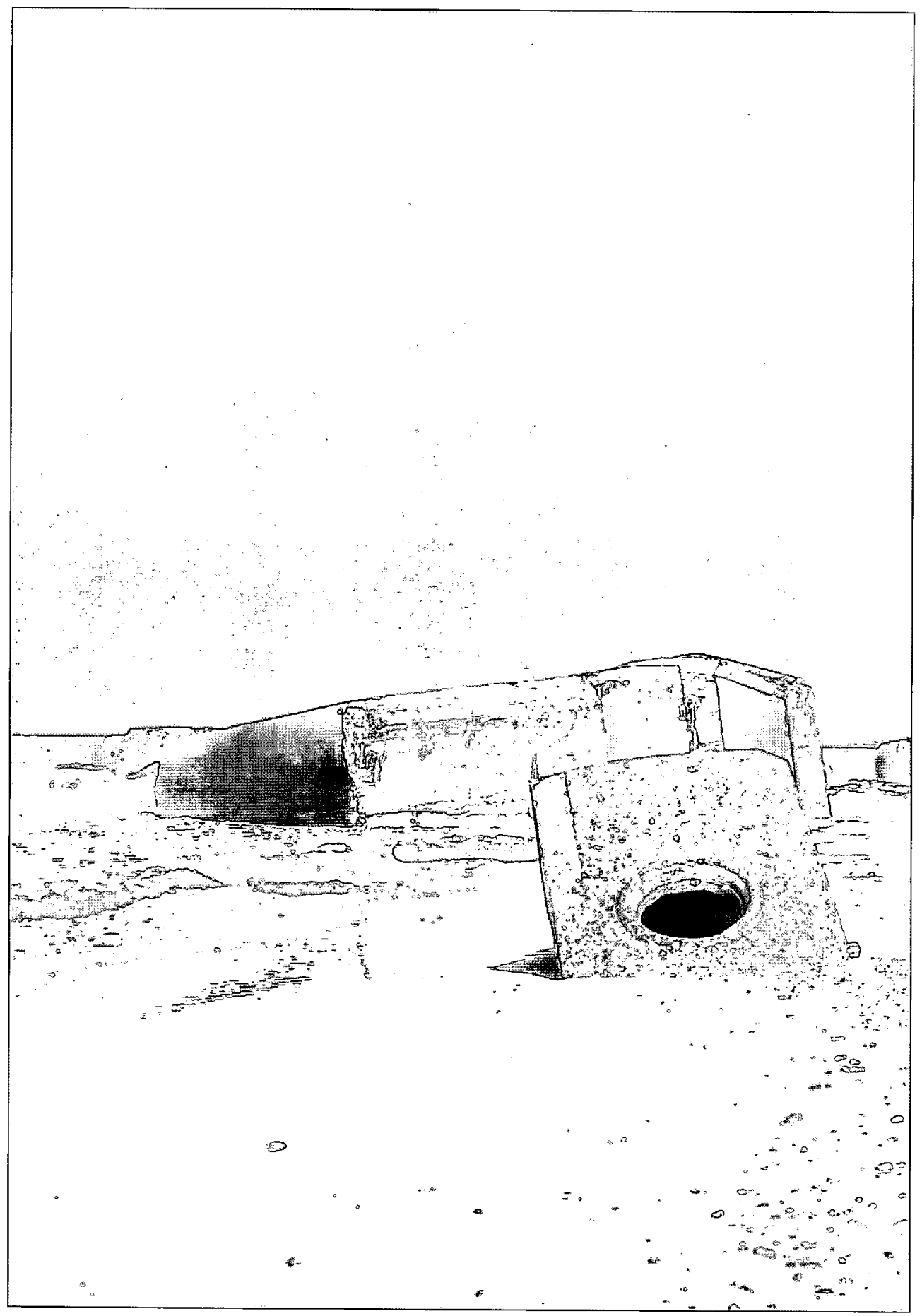

Fig. I. A part of what once formed the Atlantic Wall in Denmark. Photo: Rudi Rolf (Andersen \& Rolf 2006:3). 
importance that material remains have for reminding us about the recent past and evoking our curiosity and interest. This is a memento for the archaeology of the recent past as well as for heritage management; material remains have a great influence on what stories about the past people will tell, now and in the future. If the remains disappear and no longer remind us about the recent past, also the memories may disappear. There will, of course, always be other sources of information about the recent past, but if there is nothing to evoke our interest, we will have no reason to approach them. This does not necessarily lead to the conclusion that all physical remains from the past should be protected and preserved, but it is important to realise the very close connection between materiality and memory when making decisions about the historical landscape.

The questions that material remains give rise to cannot always be answered by studying the remains themselves, but it is nonetheless these that evoke people's interest and their urge to investigate them and their histories. Without material remains the recent past would in many cases just rest in silence and ultimately be forgotten. The removal of material remains may therefore be tantamount to a retouching of the past.

The remains from the recent past that run the greatest risk of disappearing are those which are associated with negative memories, and which therefore are not spontaneously given love and care by people. This was, for example, the case with the remains of the Atlantic Wall when Paul Virilio started his bunker archaeology. Today, however, many of these sites are protected as cultural heritage and some of them have also been turned into visitor centres (cf. Burström 2007a:45, $2007 \mathrm{~b}$ ). But there are other examples of material remains from the recent past that are now rapidly disappearing, for instance the traces from the former Communist regimes in Eastern Europe. Of course, there are some who would rather forget all bad things from the past and only remember the good. There may well be cases when this is a reasonable strategy for an individual, but for a society, and for the archaeology of the recent past as well as for heritage management, the object must be to protect people's means to remember, including the dark and painful.

\section{FRAGMENTS AS SOMETHING MORE}

When studying a period of time from which there is an abundance of sources of information it becomes particularly apparent that the interpreter's perspective determines the history told. The archaeology of the recent past often approaches the past by investigating sites where the material remains found can be linked to historically documented individuals or groups of people. It also deals with single types of artefacts and how these have been used in different contexts. It is obvious that these kinds of studies focus on very limited aspects of the big history that we know about through other sources. The question is what these fragments can add: are they more than anecdotes or historical curiosities?

The Swedish literary scholar and poet Anders Olsson (2006) has studied the 
history of fragmentary forms in literature. He traces the origin of the fragment as an aesthetic ideal to the Renaissance and the rediscovery of the classical heritage. In a concrete manner, this happened through finds of pieces of statues and remnants of texts; these fragments have an ambiguity that even today fascinates and attracts interpretation.

In contemporary poetry, the fragmentary form is expressed by means of a language that is broken into pieces, by non-structured masses of words, and by an obstinate repeating of single words. Quotations from other texts, often distorted, and references to other forms of art are also used. All in all, this means that the poetry leaves much of the production of meaning to the reader. This is often mistaken for incomprehensibility or lack of meaning.

Olsson sees a connection between the fragmentary form and modernity. When the world is regarded as too ambiguous to be able to describe in whole and rounded forms, the fragment is no longer the leftover of something that has been destroyed; instead, it is an intended form. The fragmentary becomes a reminder in form of the complexity of reality. A similar line of argument can be used concerning the archaeology of the recent past and its study of single sites or types of artefacts (Burström 2007a:85). To study that kind of remains may be regarded as a study of fragments, but the value of such studies should not be reduced to what they can add to our knowledge of the big history. Their most important contribution is instead to remind us of the existence of other realities. The big history is not the only one; there are many other stories to discover out there.

Archaeologists collect, systematise, and interpret fragments. These are usually regarded as broken or disconnected parts of a larger whole, and it is this totality one normally seeks knowledge of. But the archaeology of the recent past makes us realise that the fragment can be something even larger; it can be a way to deal with a past that is so extensive and complex that any attempt at overall description would necessarily have to be a reduction.

The study of material remains within the archaeology of the recent past is a kind of fragmentising method. The purpose is not to write an all-comprehensive history, but to pay attention to and focus on aspects of the recent past for which there is usually no room in the big history. These stories often deal with aspects that were important in the everyday life of ordinary people, with how large-scale processes and important historical events appeared to them, and with what concrete impressions they made in their lives.

Let us, then, return to the question: are the fragmentary stories told by the archaeology of the recent past anything more than anecdotes or historical curiosities? By "anecdotes" is usually meant small and distinctive stories, while a "curiosity" refers to something that is intended to create interest. Put that way, archaeology of the recent past can be considered both anecdotal and a curiosity.

An anecdotal mapping of the past is, as the American literature scholar Joel Fineman (1989) has suggested, an alternative to the big history that has occupied historians for such a long time. For the archaeology of the recent past it is a way 
to connect the big and the small history, and to give the recent past a human face. Perhaps it is only through the small stories that large processes become apprehensible and really possible to understand. And what do we know about the small history in prehistory?

\section{MATERIALITY AND MEMORY}

The power of material objects to make us remember and reflect about the past is well known. It forms the basis of a worldwide industry of souvenir production, closely related with tourism. Souvenirs help us all to remember our travels and experiences. What distinguishes souvenirs from other things is that they are produced with the intention to function as mementos, but other things may have the same function (cf. Hallam \& Hockey 2001). What is particularly interesting is their power to evoke memories that could not be reached by mere brainwork. The classic example of how an object can trigger a remembrance is a scene from the French author Marcel Proust's novel, In Search of Lost Time (1913-27). There the main character experiences the taste of a madeleine-biscuit, and it makes him suddenly remember details from his youth that he earlier has tried, but failed, to recall. This episode is famous because it illustrates how a taste, a smell, a sound, or some other sensory impression suddenly can make us remember. Proust makes a distinction between these unintentional recollections and intentional memories. Our senses help us remember that which we cannot recall solely by mental power. About our own past, Proust writes (1996:51):

It is a labour in vain to attempt to recapture it: all the efforts of our intellect must be futile. The past is hidden somewhere outside the realm, beyond the reach of intellect, in some material object (in the sensation which that material object will give us) of which we have no inkling.

How people's memories relate to the past and what importance they should be given in the writing of history is much debated (cf. e.g., Samuel 1994; Ricœur 2004). Memories, as pointed out above, may be recollections of course of events that you once experienced, or that may have been told to you by others who did. But they can also be constructions that you - intentionally or not - have created in retrospect in order to make the past and its remains understandable or bearable. What is what, is not always possible to determine. But memories do not have to be in agreement with historical facts to be of interest. In some sense memories are always true since they reflect how someone truly experienced the past or later remembers it. The fact that memories are personally coloured and subjective does not make them any less interesting. On the contrary, it contributes because it gives a human dimension to what happened in the past as we look at it through someone else's eyes.

Memories are always related to their opposite, that is to the forgotten (cf. e.g., Forty \& Küchler 1999; Ricœur 2004). Forgetting, like remembering, can be of different kinds. In some cases memories have slowly faded away and gradually 
grown into the forgotten. In other cases the forgetfulness is a result of repression, intentional or unintentional. Maybe some of us only remember what we want to remember, while history reminds us of all the rest. The French philosopher Paul Riccur (2004) has in line with this made a distinction between "Happy Memory" and "Unhappy History".

By comparing people's memories with the testimony of material remains and other sources of information it is possible to discover important dissimilarities (cf. Shackel 2000). The relation between memory and material testimony can be compared with the relation between things and text as sources of information (cf. Andrén 1998). There is no reason to choose between the study of how the past is remembered and how it appears in more conventional sources. On the contrary, these histories complete one another, and the differences found between them give us an opportunity to understand how people actually experienced the past, how they later remember it, and how they relate to it. It is important, however, to realise that people's memories often differ from one to the other and even can be contradictory. This stresses the importance of talking to many different persons and not just those who spontaneously are most interested or easy accessible.

The power inherent in material objects to make people remember is fundamental to the archaeology of the recent past. When people encounter things, and start talking with archaeologists and others about them, they suddenly remember what they otherwise would not have thought of. These memories often deal with aspects that are not found in other sources, and are invaluable to reach an understanding of the human dimension of the recent past.

A well-known problem in interacting with people and asking them about their memories and other things is that the investigation itself has an influence on the stories told and what will be remembered in the future. Sometimes the archaeology of the recent past pays attention to histories that are locally important but unknown to most outsiders. This attention is often appreciated and functions as a kind of official confirmation that the local history has a value and is worth remembering. In other cases, however, the archaeological interest is focused on sites or histories that are locally forgotten. This was, for example, the case with the excavation of the ruins of the crofter's cottage Granströms in Nyberget in the province of Dalarna (Welinder 1992, 1993a, 1993b). This investigation is well known to most Swedish archaeologists, but prior to the excavation the site was locally known only as a place where people used to pick bilberries (Welinder 1992b:17). Now that has changed. This can, of course, be described as a positive rediscovery of local history, but it also raises questions about what histories are important and who is to decide.

Human memory does not have the kind of straightforward chronology that history - and archaeology - forces on the past. Let us return to Marcel Proust; as a modernistic author he broke with the preceding, realistic tradition. He did not content himself with describing an external course of events, but chose to start from a subjective consciousness from which he describes the inner life of the 
individual. This means that the chronology is turned into pieces and the story does not follow any simple time-bound order; instead it is composed of a stream of thoughts, memories, and associations where now, then, and later are mixed with one another. The result can be compared to the collage within visual art. It forms a new context where events separated in time are brought together, sometimes in surprising combinations, and give each other meaning. I believe that there may be important qualities for archaeology to explore in this kind of chronological mixture and apparent confusion. Some aspects of the recent as well as the distant past may in fact be more clearly seen in a less strictly defined chronological frame.

\section{THE EXISTENTIAL DIMENSION}

The thoughts that material remains evoke are not limited to the past. They also evoke reflections about eternal human concerns such as the passing of time, continuance and perishableness, life and death, and what is important and unimportant in our lives.

These kinds of reflections are, for example, a decisive reason that thousands of people have found their way to a deserted old car dump in southern Sweden (cf. Burström 2007a:70-75, Burström 2008). Here we find more than a hundred car wrecks dating from the 1930s to the 1970s, wrecks that are in various stages of breaking down (Fig. 2). What just a short time ago were fast and modern means of transportation and symbols of status are now quietly being recaptured by nature. This ongoing disintegration fascinates people and has made them almost go on pilgrimages to the car cemetery - there are roughly between 5,000 and 15,000 visitors a year. Eaten away by rust, with empty gaping headlights, and with trees penetrating their way through the sheet iron, the car wrecks evoke existential reflections. The relatively young age and everyday character of the car wrecks seem to increase their imaginative power, and people experience the car cemetery in almost spiritual terms. The question is whether or not there is room for this kind of existential reflection within archaeology as a scholarly discipline.

The Swedish historian Håkan Arvidsson (2000) has in a discussion concerning research within the humanities argued that scholars within this field are trying to adopt a scientific ideal that threatens to destroy them. He writes (my translation):

Instead of scholarship, insight, and survey, they are reducing their field of vision to microscopic proportions, or else they let themselves go up to theorising of cosmic proportions. (...) The soul of the humanities is the learned, almost contemplative reflection, and its truths are a form of aesthetical ahaexperiences. The issues at the core of humanistic interest are the big, not to say the eternal questions - the meaning of life and death, the view on reality, the experience of love, and so forth. These are questions that lack definite answers. (...) They are at the same time, however, questions that we all constantly ponder over, questions that disquiet us, and which we have an unquenchable need to talk about. 


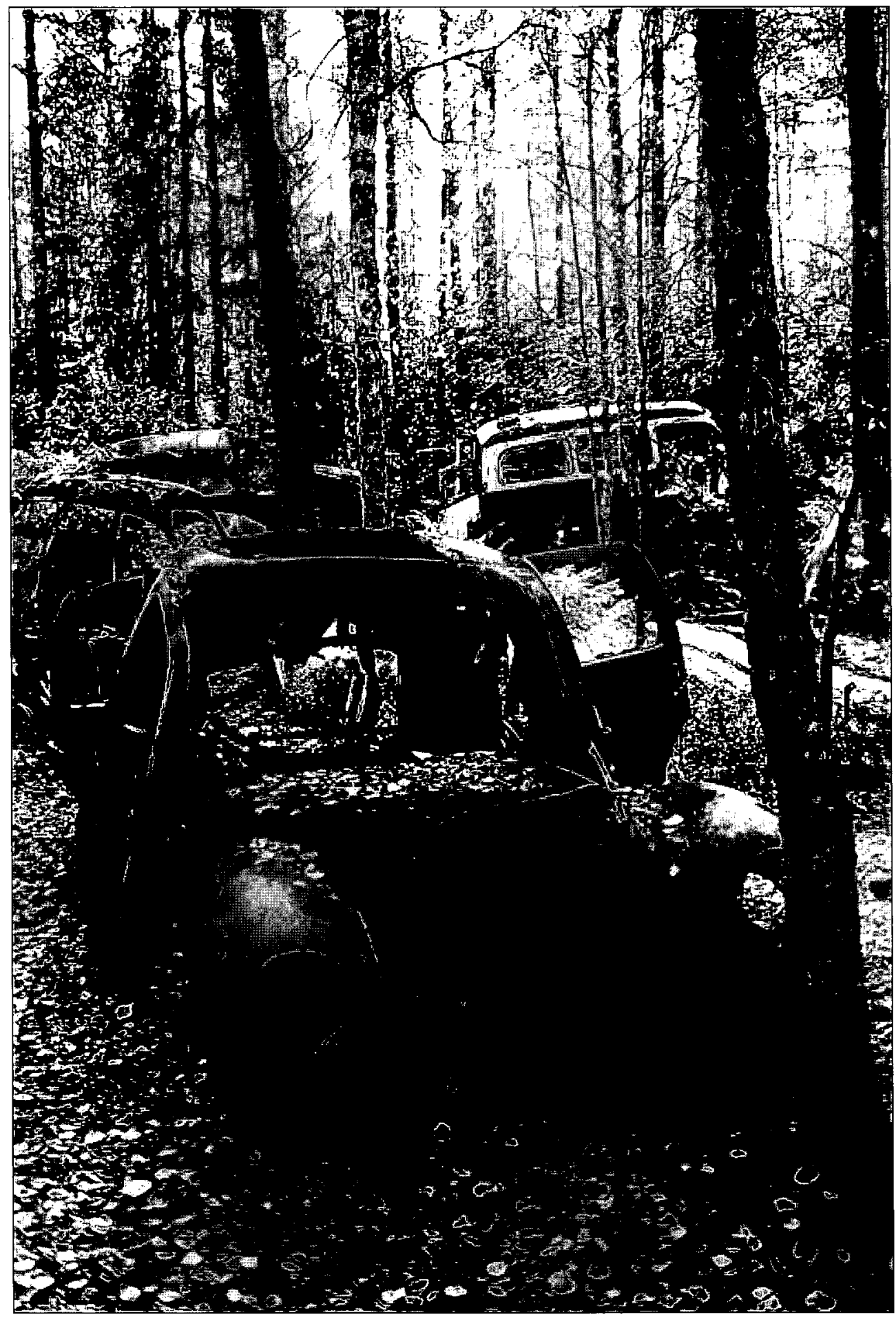

Fig. 2. Old car wrecks appear as a modern vanitas motif. Photo: Mats Burström. 
In its entirety the humanities need, of course, both the microscopic and the cosmic proportions, but I believe Arvidsson well describes how the big questions that ought to be in the focus of interest instead are those that in practice often fall outside. The reasons, surely, are to be found within the positivist ideal of science that has dominated for such a long time. It has led to a situation where what is perceived of as Knowledge and Reason have been given priority over experience and emotion. The latter are generally regarded as too subjective to be ascribed scientific value.

A positivist ideal also means that questions that can be given reasonable, sure answers are preferred over questions that per definition lack absolute or definite answers. Reflections concerning the human existence at large run the risk of being stamped as unscientific speculation or metaphysics. Outside the strictly scientific field, however, it is often precisely this kind of existential reflection that has motivated an interest in the past and its remains (cf. Lowenthal 1985; Renfrew 2003; Burström 2004).

As a scholarly discipline archaeology has a unique knowledge of how time and the passing of time become materialised and manifest in people's lives. In spite of this, we seldom contribute to more general reflections about the human existence. Instead we tend to reduce our perceptions of remains from the past so that they merely appear as potential sources of information of what once was. Archaeologists have by tradition a special relation to the ruins of the past. The Finno-Swedish author Göran Schildt has described this (1957:157, my translation):

As a matter of fact, archaeologists and ruins are, in a way, enemies. The archaeologist sees in the ruin just what it was before it became a ruin, he wants to search into the practical purpose of the building and he does everything he can to conserve what he finds, he lifts the remains that have been severely damaged by time out of time so that they will not be more ruined.

Schildt admits a certain understanding for this archaeological attitude, but states:

From the specific point of view of what could be called the poetical or philosophy of life, all conservation is a loss, because it deprives the ruin of its most important characteristic, the relation to Time. Is there anything that could give us a more living idea of the peculiar dimension of time and our own place in this than these pieces of wreckage (...)?

To Schildt ruins have a value as such, and it is interesting to note that ruins and other remains dating from the recent past seem to have a special power to strike people (cf. Hamm \& Steinberg 2000; Burström 2008). It is as if the relative nearness in time makes the ravages of time more obvious than otherwise. It reminds us that our own existence is bounded in time, and it makes us think about our place in a larger historical context.

Many archaeologists have experienced - not without frustration - that it is often the most present-day artefacts found in an excavation that attract the most 
interest from the public. These are things that people recognise from their own past, and this recognition surely promotes their popularity. But also the insight that objects that people still remember from their own time can already be of archaeological interest, leaves a strong impression on many and generates reflection. The thoughts carry from the present to the recent past, and further on to questions that are beyond chronological and disciplinary borders.

\section{CONCLUSION}

The archaeology of the recent past finds and gives voice to other stories than those dominating the big history. But it also recognises that things and other material remains are much more than just sources of information; they also touch people, make them remember, and evoke reflections about large and small in the human existence: What is left from the past and what has disappeared? What will we leave after us? How will the future remember us? Do we care? Why, or why not?

These questions cannot, of course, be given any absolute or definite answers. But there is nothing unique about this; on the contrary, it applies to many or most archaeological questions. In spite of this, the emotional and existential dimensions of the past and its remains have by tradition fallen outside the scholarly field of archaeology. The issue of what material remains from the past do with us archaeologists and others - who are living today, has been considered too personal or subjective to be approached. The archaeology of the recent past now brings this issue to the fore and with it general considerations on the epistemological borders of archaeology.

ACKNOWLEDGEMENTS

My warm thanks to Nanouschka Myrberg, Stockholm University, and Cornelius Holtorf, Lund University, for their comments on an earlier version of this paper. Thanks also to Rudi Rolf, the Netherlands, for kind permission to use his photo. 


\section{REFERENCES}

Andersen, J. \& Rolf, R. 2006. German Bunkers in Denmark. A Survey. PRAK Publishing. Middelburg.

Andrén, A. 1998 [1997]. Between Artifacts and Texts. Historical Archaeology in Global Perspective. Plenum Press. New York.

Arvidsson, H. 2000. Humanistisk reflektion gör kunskap av information. Svenska Dagbladet (Daily paper), 2000-09-20.

Bodin, S., Hulling, H., Pettersson, S. \& Svensson, E. 2005. Olika perspektiv på föremål. Materiell kultur hos obesuttna ca 1900. META, 1/2005. Pp. 3-20.

Buchli, V. \& Lucas, G. (Eds) 2001. Archaeologies of the Contemporary Past. Routledge. London.

Burström, M. 2004. Archaeology and existential reflection. In: Bolin, H. (Ed.) The Interplay of Past and Present. Södertörn Archaeological Studies 1. Huddinge. Pp. 20-28.

Burström, M. 2007a. Samtidsarkeologi. Introduktion till ett forskningsfält. Studentlitteratur. Lund.

Burström, M. 2007b. Vi behöver tingen för att minnas. Svenska Dagbladet, (Daily paper), 2007-01-18.

Burström, M. 2008. Garbage or heritage. The existential dimension of a car cemetery. In: Holtorf, C. \& Piccini, A. (Eds.) Contemporary Archaeologies - Excavating Now. Peter Lang, Frankfurt am Main. Pp. 133-145.

Burström, M., Gustafsson, A. \& Karlsson, H. 2006. The air torpedo of Bäckebo. Local incident and world history. Current Sivedish Archaeology, Vol. 14, 2006. Pp. 7-24.

Fåhraeus, F., Ganneby, S., Lunnemo, M., Schultzén, J. \& Petré, B. 2005. Flyktinglägret från 1940-talet på Lovö. Elonora-Posten. Lovö Hembygdsförenings tidning, Nr 1, 2005. Pp. 4- 10.

Fineman, J. 1989. The history of the anecdote: fiction and fiction. In: Veeser, A. (Ed.) The New Historicism. Routledge. London \& New York. Pp. 49-76.

Forty, A. \& Küchler, S. (Eds) 1999. The Art of Forgetting. Berg. Oxford \& New York.

Gould, R. A. \& Schiffer, M. B. (Eds) 1981. Modern Material Culture. The Archaeology of Us. Academic Press. New York.

Hallam, E. \& Hockey, J. 2001. Death, Memory and Material Culture. Berg. Oxford

Hamm, M. \& Steinberg, R. 2000 [1981]. Dead Tech. A Guide to the Archaeology of Tomorrow. Hennessey \& Ingalls. Santa Monica.

Hammar, L-E. \& Lindholm. K. 2005. Snarsmon - resandefolkets boplats i Bullaren. Bohusläns Arsbok. 2005. Pp. 152-166.

Hansson, L. \& Thor, M. (Eds) 2006. Muntlig historia. Studentlitteratur. Lund.

Holyoak, V. \& Schofield, J. 2002. Militany Aircraft Crash Sites. Archaeological guidance on their significance and future management. English Heritage. London.

Isacson, M. 2003. Industrisamhällets faser och industriminnesforskningens uppgifter. In: Avango, D. \& Lundström, B. (Eds) Industrins avtryck. Perspektiv på ett forshningsfält. Brutus Östlings Bokförlag Symposium. Stockholm/Stehag. Pp. 21-47.

Legendre, J-P. 2001. Archaeology of World War 2. The Lancaster bomber of Fléville (Meurthe-et-Moselle, France). In: Buchli, V. \& Lucas, G. (Eds) Archaeologies of the Contemporary Past. Routledge. London \& New York. Pp. 126-137.

Lihammer, A. 2006. Krampen - ett interneringsläger från 1940-talet. Kulturmiljövård Mälardalen. Rapport 2006:24. Stiftelsen Kulturmiljövård Mälardalen. Västerås.

Lind, H. \& Svensson, E. 2001. Sentida bebyggelse i antikvarisk och arkeologisk verksamhet. In: Lind, H., Svensson, E. \& Hansson [Ulin], J. Sentida bebyggelse i antikvarisk och arkeologisk verksamhet. Riksantikvarieämbetet. Stockholm. Pp. 6-46.

Lindholm, K. 2006. Resandebosättningen på Snarsmon. Arkeologisk forskningsundersökning, del 2. Bohusläns museum, Rapport 2006:47. Uddevalla.

Lowenthal, D. 1985. The Past is a Foreign Country: Cambridge University Press. Cambridge.

McChord Crothers, S. 1903. The Gentle Reader: Riverside Press. Boston \& New York.

Olsson, A. 2006. Skillnadens konst. Sex kapitel om moderna fiagment. Albert Bonniers förlag. Stockholm.

Persson, M. 2006. Modernitet och materialitet - sentida kulturarv med arkeologisk blick. Rapport över projektets utgrävning av Ramneskärsparken, Herrestads sn, Västra Götalands län. Bohusläns museum, Rapport 2006:46. Uddevalla. 
Proust, M. 1996 [1913]. In Search of Lost Time, Vol. I, Swann's Wav. Vintage. London.

Rathje, W. 2001. Integrated archaeology. A garbage paradigm. In: Buchli, V. \& Lucas, G. (Eds) Archaeologies of the Contemporary Past. Routledge. London \& New York. Pp. 63-76.

Rathje, W. \& Murphy, C. 2001 [1992]. Rubbish! The Archaeology of Garbage. The University of Arizona Press. Tucson.

Renfrew, C. 2003. Figuring It Out. Thames \& Hudson. London.

Ricour, P. 2004 [2000]. Memory; History; Forgetting. The University of Chicago Press. Chicago.

Samuel, R. 1994. Theaters of Memory. Past and Present in Contemporary Society. Verso. London.

Schildt, G. 1957. Ikaros ' hav. Wahlström \& Widstrand. Stockholm.

Schofield, J. 2005. Combat Archaeology. Material Culture and Modern Conflict. Duckworth. London.

Shackel, P. A. 2000. Archaeology and Created Memory. Public History in a National Park. Kluwer Academic/Plenum Publishers. New York.

Taylor, T. 1999. The Ultimate Time Team Companion. An Alternative History of Britain. Channel 4 Books. London.

Ulin, J. 2004. Turning into the walkscape of the family. In: Campbell, F. \& Ulin, J. Border Line Archaeology: a practice of contemporary archaeology - exploring aspects of creative narratives and performative cultural production. Göteborgs universitet. Diss. Pp. 168-234.

Virilio, P. 1994. Bunker Archaeology. Princeton Architectural Press. New York.

Welinder. S. 1992. Miljö, kultur och kulturmiljö. Almqvist \& Wiksell International. Stockholm.

Welinder, S. 1993a. Människor och artefaktmönster. Occasional Papers in Archaeology 5. Uppsala.

Welinder, S. 1993b. Människor och landskap. Societas Archaeologica Upsaliensis. Aun 15. Uppsala.

Wienberg, J. 2005. Historisk arkæologi i samtiden. META, 2/2005. Pp. 66-78.

www.tidaholm.se/kultur/klappeb_arkeologi.htm 